\title{
The effect of selected factors on the quality of life of patients after arthroscopic reconstruction of a rotator cuff 1-2 years after surgery
}

\section{Wpływ wybranych czynników na jakość życia pacjentów po artroskopowej rekonstrukcji stożka rotatorów w ciągu 1-2 lat od zabiegu}

\author{
Agnieszka Bejer ${ }^{1,2}$, Sabina Mastej ${ }^{3}$, Jędrzej Płocki ${ }^{2,4}$, Mirosław Probachta², Marek Kulczyk ${ }^{5}$, Ireneusz Kotela ${ }^{6,7}$ \\ 'Department of Medicine, Institute of Physiotherapy, Faculty of Medicine, University of Rzeszow, Rzeszow, Poland \\ Head of the Department: Prof. UR Lidia Perenc PhD \\ 2Department of Rehabilitation, Holy Family Specialist Hospital, Rudna Mała, Poland \\ Head of the Department: Bożena Sałata MD \\ 3Department of Rehabilitation, Health Centre Dr Mastej, Jasło, Poland \\ Head of the Centre: Mirosław Mastej MD \\ ${ }^{4}$ Chair of Physiotherapy, Department of Medicine, University of Information Technology and Management with Seat, Rzeszow, Poland \\ Head of the Department: Helena Bartyzel-Lechforowicz PhD \\ ${ }^{5}$ Department of Orthopaedics, Holy Family Specialist Hospital, Rudna Mała, Poland \\ Head of the Department: Marek Kulczyk MD \\ ${ }^{6}$ Department of Orthopaedics and Traumatology Clinic of Orthopaedics and Traumatology, Central Clinical Hospital of the Ministry \\ of Internal Affairs, Warsaw, Poland \\ Head of the Department: Prof. Ireneusz Kotela MD, PhD \\ ${ }^{7}$ Department of Rehabilitation in Disease of the Locomotor, Institute of Physiotherapy, Faculty of Medicine and Health Sciences, \\ Jan Kochanowski University, Kielce, Poland \\ Head of the Department: Prof. Ireneusz Kotela MD, PhD
}

Key words: quality of life, shoulder joint, rotator cuff, arthroscopy.

Słowa kluczowe: jakość życia, staw ramienny, stożek rotatorów, artroskopia.

\begin{abstract}
Introduction: One of the key goals in the recovery process in patients after the procedure of surgical repair of the rotator cuff is the reduction of pain complaints and achievement of satisfactory improvement in such domains as occupational activity, lifestyle, sports, recreation, or mood.

Aim of the research: To evaluate the effect of selected factors on the quality of life of patients who had undergone arthroscopic reconstruction of the rotator cuff within 1-2 years of the surgery.

Material and methods: The study was conducted in a group of 69 patients aged 40-65 years, after arthroscopic reconstruction of the rotator cuff in the Specialist Hospital in Rudna Mała. The quality of life was measured using the WORC, which is a disease-specific research instrument.

Results: The highest quality of life was noted subsequently in the following domains: physical symptoms $(\bar{x}=22.28)$, emotions $(\bar{x}=24.21)$, and lifestyle $(\bar{x}=26.74)$, whereas the lowest quality of life was seen in the domains of work $(\bar{x}=38.48)$ and sports and recreation $(\bar{x}=36.18)$. The highest overall quality of life was observed in patients with university education level ( $p=0.011)$, occupationally active $(p=0.017)$, who performed intellectual work $(p=0.001)$, and received rehabilitation for a period longer than 8 weeks ( $p=0.003)$.

Conclusions: The respondents' university education level, occupational activity, intellectual work, and rehabilitation for a period longer than 8 weeks were the factors that strongly determined the quality of life of patients. Physical symptoms, such as the domain of the WORC, most strongly determined the overall quality of life of the respondents.
\end{abstract}

\section{Streszczenie}

Wprowadzenie: $\mathrm{W}$ procesie zdrowienia pacjentów po zabiegu rekonstrukcji pierścienia rotatorów jednym z kluczowych celów jest zmniejszenie dolegliwości bólowych i osiągnięcie zadowalającej poprawy w takich obszarach jakości życia, jak aktywność zawodowa, styl życia, sport, rekreacja czy nastrój.

Cel pracy: Ocena wpływu wybranych czynników na jakość życia pacjentów po artroskopowej rekonstrukcji stożka rotatorów w okresie 1-2 lat od zabiegu.

Materiał i metody: Badania przeprowadzono u 69 osób po artroskopowej rekonstrukcji stożka rotatorów w wieku 40-65 lat, operowanych w latach 2015-2016 w Szpitalu Specjalistycznym im. Świętej Rodziny w Rudnej Małej. Pomiaru jakości życia dokonano przy użyciu kwestionariusza WORC, który jest specyficznym narzędziem badawczym umożliwiającym ocenę jakości życia pacjentów w pięciu kategoriach. 
Wyniki: Najlepsza jakość życia odnotowano kolejno w nasteppujących dziedzinach: objawy fizyczne $(\bar{x}=22,28)$, emocje $(\bar{x}=24,21)$ i styl życia $(\bar{x}=26,74)$, a najgorszą jakość życia w dziedzinach praca $(\bar{x}=38,48)$ oraz sport i rekreacja $(\bar{x}=36,18)$. Lepszą ogólną jakością życia cechowały się osoby z wyższym wykształceniem $(p=0,011)$, aktywne zawodowo $(p=0,017)$, pracujące umysłowo $(p=0,001)$ oraz rehabilitowane przez okres powyżej 8 tygodni $(p=0,003)$.

Wnioski: Wyższe wykształcenie, aktywność zawodowa, praca umysłowa oraz rehabilitacja powyżej 8 tygodni są czynnikami, które silnie determinują jakość życia pacjentów. Objawy fizyczne jako dziedzina WORC najsilniej warunkują ogólną jakość życia badanych.

\section{Introduction}

The shoulder girdle, also referred to in literature as the shoulder complex, is one of the most biomechanically complex structures in the human motor system. It is composed of three anatomical joints and two functional joints [1]. Its structure provides very high mobility with a simultaneously sufficient stability of the upper extremity while performing movements in space, provided that the proper balance between all muscles engaged in movement is maintained. Unfortunately, this is also the cause of frequent injuries related mainly with an abnormal distribution of the pulling forces exerting an effect on the periarticular soft tissues [2].

Muscular imbalance most often affects the socalled rotator cuff muscles, which insert into the greater tubercle of the humerus where, during motion, they enter the structural system with the acromion and other soft tissues, which increases the risk of tissue conflict $[3,4]$. The subsequent overloads and micro-injuries ultimately contribute to damage to the rotator cuff muscles. Such damage is manifested, among others, by the lack of active shoulder abduction while maintaining passive motion, weakening of muscle strength or atrophy of rotator cuff muscles, and a partial or total loss of function, manifested by an incapability of performing occupational activity, physical work, or other simple activities such as dressing, hygiene activities, etc. [5, 6].

At present, arthroscopic reconstruction of the rotator cuff, followed by complex rehabilitation, is one of the most common and effective minimally invasive methods of treatment of this type of injury. Such a scheme of therapeutic management results in a considerable improvement in the quality of life of patients affected by this dysfunction [7-10].

The World Health Organisation (WHO) defines quality of life as 'an individual's perception of their position in life in the context of the culture and value systems in which they live and in relation to their goals, expectations, standards, and concerns' [11]. The quality of life is the concept widely assessing several basic aspects of life related with the physical and mental health of a patient and his/her social position [12]. One of the key goals in the recovery process in patients after the procedure of surgical repair of the rotator cuff is the reduction of pain complaints and achievement of satisfactory improvement in such domains as occupational activity, lifestyle, sports, recreation, or emo- tional sphere. The quality of life may be assessed using global scales and disease-specific scales. The global (generic) scales assess the quality of life of patients in a relatively general way, usually considering several dimensions, and serve mainly for the evaluation and comparison between various study groups. Examples of such scales include, among others: the Short Form Health Survey (SF-36) and the EQ-5D. In turn, diseasespecific scales are applied to assess the quality of life of patients with a particular disease entity and focus on symptoms typical of a given entity. These scales allow the monitoring of a patient's responses to treatment and application of various forms of therapy. They are characterised by high sensitivity to changes, and compared to global scales, apart from the typical domains of life, they also include examples of actions or functions which might have been negatively affected by an injury or disease $[13,14]$.

Unfortunately, in Polish literature, the number of reports concerning the quality of life of patients who have undergone the rotator cuff repair surgery using standardised research instruments is scarce; therefore, the presented study was undertaken using a disease-specific questionnaire.

\section{Aim of the research}

The objective of the study was to assess the domains of the quality of life in which patients after arthroscopic reconstruction of the rotator cuff functioned best within the distant period after the surgery, and which domains were still affected by the injury. The relationships were also evaluated between the quality of life of these patients and selected factors, such as: gender, age, place of residence, education level, occupational activity, type of work performed, marital status, dominance of the surgical limb, physical activity, and participation in physiotherapy.

\section{Material and methods}

The study was conducted among patients who had undergone arthroscopic reconstruction of the rotator cuff performed in the Holy Family Specialist Hospital in Rudna during 2015-2016. The criteria of qualification for the study were: age from 40-65 years and the patient's informed and voluntary consent to participate in the study. The exclusion criteria were as follows: past surgeries within the shoulder complex, past fractures of the proximal end of the humerus, acetabular cup, collarbone or acromion, past disloca- 
tions within the shoulder complex, and concomitant neurological disorders.

The study comprised 69 patients: 20 (29\%) females and $49(71 \%)$ males, $36(52 \%)$ of whom lived in rural areas, and $33(48 \%)$ of whom urban inhabitants; 55 $(80 \%)$ were married or lived in a non-marital partnership, whereas 14 (20\%) respondents were divorced, unmarried, or widowed. Only in 11 (16\%) patients was the surgery performed on the non-dominant limb. Forty-three (62\%) respondents were occupationally active, among whom 25 (58\%) performed physical work and 18 (42\%) intellectual work. Only $29(42 \%)$ respondents were engaged in physical activity, while the remaining $40(58 \%)$ patients preferred passive leisure. After the surgery, as many as 68 (99\%) patients participated in physiotherapy, including 37 (54\%) who had undergone therapy lasting up to 8 weeks altogether, and 31 (46\%) participated in physiotherapy for longer than 8 weeks.

\section{Research instrument}

The Western Ontario Rotator Cuff Index (WORC) is a disease-specific research tool for the assessment of the quality of life of patients with various rotator cuff problems. It contains 21 items grouped into five domains - physical symptoms (six items), sports and recreation (four items), work (four items), lifestyle (four items), and emotions (three items). The respondents provide answers concerning symptoms and problems observed within the last week. The total score may be calculated for each domain (Physical symptoms/600; Sports and recreation/400; Work/400; Lifestyle/400; Emotions/300). The highest possible result in the whole questionnaire is 0 , while the lowest is 2100 .

In order to make scoring more understandable the authors of the test recommend the conversion of raw results to percentage scores. The percentage result is obtained by inverting the raw score and expressing it in the form of a percentage in relation to the possible maximum result. Zero per cent is the worst possible, while $100 \%$ is the best possible result $[15,16]$.
An author-designed questionnaire was used to collect personal and clinical data, including: age, gender, place of residence, marital status, education, occupational activity, type of occupation performed, dominance of the surgical limb, and participation in physiotherapy.

\section{Statistical analysis}

Statistical analysis of the collected material was performed using the software package Statistica 13.1. The normality of distribution of the sub-scales of the WORC and aggregate score was assessed by means of the Shapiro-Wilk Test. The distributions of the analysed variables significantly differed from normal distribution; therefore, exclusively non-parametric tests were used for analyses. The differences between two groups were assessed using Mann-Whitney $U$ test, whereas the differences between three or more groups were assessed by means of Kruskall-Wallis test. If the result of Kruskal-Wallis test was statistically significant, post-hoc analysis was applied using multiple comparison procedure in order to determine the sub-groups that were significantly different from one another. Correlations between the variables were evaluated using Spearman's rank-order correlation coefficient. The $p$-values $<0.05$ were considered statistically significant.

\section{Results}

The respondents presented the lowest quality of life in the domain of work $(\bar{x}=61.52)$ and sports and recreation $(\bar{x}=63.83)$, whereas they achieved the highest results in the domain physical symptoms $(\bar{x}=77.72)$, followed by emotions $(\bar{x}=75.79)$ and lifestyle $(\bar{x}=73.26)$. The highest level of functioning assessed according to the WORC is $100 \%$, while the patients in this study obtained $70.86 \%$ on average (within the range 24-100\%) (Table 1).

It was investigated which domains of life exerted the greatest effect on the overall quality of life of the respondents. It was found that all domains of the WORC strongly and statistically significantly deter-

Table 1. Respondents' quality of life according to the WORC - overall result and individual domains

\begin{tabular}{|lcccccccc|}
\hline WORC [\%] & \multicolumn{10}{c|}{ Descriptive statistics } \\
\cline { 2 - 10 } & $\boldsymbol{N}$ & $\overline{\boldsymbol{x}}$ & $\mathbf{M e}$ & $\mathbf{M i n}$. & Max. & Q1 & Q3 & SD \\
Physical symptoms & 69 & 77.72 & 83.33 & 33.50 & 100.00 & 59.83 & 94.67 & 20.42 \\
Sports and recreation & 69 & 63.83 & 74.50 & 7.75 & 100.00 & 40.00 & 90.50 & 29.17 \\
Work & 69 & 61.52 & 64.50 & 0.00 & 100.00 & 33.25 & 92.50 & 31.31 \\
Lifestyle & 69 & 73.26 & 81.25 & 18.75 & 100.00 & 53.00 & 97.25 & 26.02 \\
Emotions & 69 & 75.79 & 85.00 & 18.00 & 100.00 & 58.33 & 97.33 & 24.69 \\
Total & 69 & 70.86 & 78.14 & 24.00 & 100.00 & 49.57 & 93.95 & 24.50 \\
\hline
\end{tabular}

WORC - Western Ontario Rotator Cuff Index, $n$ - number of observations, $\bar{x}$ - arithmetic mean, Me - median, Min. - minimum, Max. - maximum, Q1 - lower quartile, Q3 - upper quartile, SD - standard deviation. 
mined the overall quality of life. However, physical symptoms occupied the first position, as the domain that most strongly determined the overall result of the scale (Table 2).

Subsequently, an assessment was undertaken of the effect of selected factors on the quality of life. The overall quality of life of females was higher $(\bar{x}=75.77 \%)$ than that of males $(\bar{x}=68.86 \%)$; however, these differences were statistically insignificant $(p=0.355)$. The results in all domains of the WORC were higher in females than in males but were statistically insignificant. No statistically significant correlations were observed between the respondents' quality of life and their age ( $p=0.249)$. Also, no relationship was found between the quality of life of the examined patients and their marital status $(p=0.612)$. No statistically significant differences in overall quality of life were noted between respondents living in rural or urban areas $(p=0.220)$. Nor were any such relationships discovered in any of the WORC domains in the above-mentioned groups.

While analysing the effect of education on the quality of life, a clear relationship may be observed
Table 2. Correlations between particular domains of life and overall result according to the WORC

\begin{tabular}{|lcc|}
\hline WORC domains vs. overall WORC & $R$ & $P$-value \\
$\begin{array}{l}\text { Physical symptoms vs. overall } \\
\text { WORC }\end{array}$ & 0.9634 & $<0.001$ \\
$\begin{array}{l}\text { Sports and recreation vs. overall } \\
\text { WORC }\end{array}$ & 0.9481 & $<0.001$ \\
Work vs. overall WORC & 0.9606 & $<0.001$ \\
Lifestyle vs. overall WORC & 0.9335 & $<0.001$ \\
Emotions vs. overall WORC & 0.8252 & $<0.001$ \\
\hline
\end{tabular}

WORC - Western Ontario Rotator Cuff Index, $R$ - value of Spearman rank correlation, $p$ - level of significance of differences.

that the higher the level of education the better the quality of life $(p=0.011)$, and the quality of life in the following domains: physical symptoms $(p=0.010)$, sports and recreation $(p=0.017)$, work $(p=0.010)$, and lifestyle $(p=0.046)$ (Table 3$)$.

Table 3. Relationships between respondents' quality of life according to the WORC and education level

\begin{tabular}{|c|c|c|c|c|c|c|c|c|c|c|c|}
\hline \multirow[t]{2}{*}{ WORC [\%] } & \multicolumn{3}{|c|}{ Primary/vocational } & \multicolumn{3}{|c|}{ Secondary school } & \multicolumn{3}{|c|}{ University } & \multirow[t]{2}{*}{$H$} & \multirow[t]{2}{*}{$P$-value } \\
\hline & $\bar{x}$ & $\mathrm{Me}$ & SD & $\bar{x}$ & Me & SD & $\bar{x}$ & $\mathrm{Me}$ & SD & & \\
\hline $\begin{array}{l}\text { Physical } \\
\text { symptoms }\end{array}$ & 71.72 & 74.67 & 21.26 & 76.73 & 83.00 & 20.66 & 91.98 & 93.50 & 9.88 & 9.10 & 0.010 \\
\hline $\begin{array}{l}\text { Sports and } \\
\text { recreation }\end{array}$ & 57.25 & 50.63 & 29.62 & 60.91 & 54.25 & 28.29 & 84.70 & 90.00 & 16.59 & 8.06 & 0.017 \\
\hline Work & 50.81 & 50.13 & 32.03 & 61.72 & 61.00 & 30.71 & 83.18 & 88.75 & 19.22 & 9.21 & 0.010 \\
\hline Lifestyle & 68.51 & 69.13 & 25.22 & 70.70 & 80.00 & 27.59 & 90.02 & 94.50 & 13.64 & 6.15 & 0.046 \\
\hline Emotions & 74.39 & 84.33 & 25.64 & 71.93 & 79.00 & 23.53 & 88.11 & 96.67 & 19.44 & 4.88 & 0.086 \\
\hline Total & 64.75 & 62.76 & 24.14 & 69.02 & 73.71 & 24.98 & 87.99 & 92.52 & 14.59 & 8.94 & 0.011 \\
\hline
\end{tabular}

WORC - Western Ontario Rotator Cuff Index, $\bar{x}$ - arithmetic mean, Me - median, SD - standard deviation, $\mathrm{H}$ - result of Anova KruskalWallis test, $p$ - level of significance of differences.

Table 4. Relationships between quality of life according to WORC and occupational activity

\begin{tabular}{|c|c|c|c|c|c|c|c|c|}
\hline \multirow[t]{2}{*}{ WORC } & \multicolumn{3}{|c|}{ Occupationally active } & \multicolumn{3}{|c|}{ Occupationally inactive } & \multirow[t]{2}{*}{$Z$} & \multirow[t]{2}{*}{$P$-value } \\
\hline & $\bar{x}$ & Me & SD & $\bar{x}$ & Me & SD & & \\
\hline Physical symptoms & 83.30 & 92.67 & 18.32 & 68.49 & 63.75 & 20.69 & -2.56 & 0.010 \\
\hline Sports and recreation & 70.89 & 83.00 & 27.69 & 52.14 & 42.88 & 28.24 & -2.35 & 0.019 \\
\hline Work & 70.47 & 79.75 & 27.27 & 46.72 & 35.63 & 32.42 & -2.76 & 0.006 \\
\hline Lifestyle & 78.71 & 92.25 & 24.22 & 64.24 & 63.38 & 26.83 & -1.93 & 0.053 \\
\hline Emotions & 79.11 & 85.33 & 22.43 & 70.31 & 79.33 & 27.61 & -0.92 & 0.358 \\
\hline Total & 77.02 & 83.38 & 22.31 & 60.68 & 53.64 & 24.97 & -2.38 & 0.017 \\
\hline
\end{tabular}

WORC - Western Ontario Rotator Cuff Index, $\bar{x}$ - arithmetic mean, Me - median, SD - standard deviation, Z - result of Mann-Whitney $U$ test, $p$ - level of significance of differences. 
Analysis performed using post-hoc multiple comparison procedure showed the presence of significant differences between the results obtained in group 1 (Primary/vocational) and group 3 (University) in the domains: physical symptoms $(p=0.008)$, sports and recreation $(p=0.017)$, work $(p=0.007)$, lifestyle $(p=0.045)$, and overall quality of life $(p=0.009)$. However, in none of the above-mentioned domains were significant differences observed between the results obtained in group 1 (Primary/vocational) and group 2 (Secondary school) and group 3 III (University).

It was confirmed that respondents who were occupationally active presented a higher overall quality of life ( $p=0.017)$, and in the following domains: physical symptoms $(p=0.010)$, sports and recreation $(p=0.019)$ and work $(p=0.006)$, compared to those inactive occupationally (Table 4 ).

At the same time, the respondents who performed intellectual work showed a statistically higher quality of life than those who performed physical work ( $p=0.001)$, and in all the domains assessed: physical symptoms $(p=0.001)$, sports and recreation $(p=0.002)$, work $(p=0.002)$, lifestyle $(p=0.002)$, and emotions $(p=0.010)$.

No relationship was found between the respondents' quality of life and the surgical upper limb according to dominance $(\bar{x}=0.796)$. However, slightly better results were obtained when the surgery concerned the non-dominant limb.

The respondents who were physically active showed a higher overall quality of life, and in all domains; nevertheless, these relationships were statistically insignificant ( $p=0.706)$.

Very clear relationships were observed between the duration of rehabilitation and the quality of life. The respondents who visited a physiotherapist for therapy for a period longer than 8 weeks showed a statistically higher quality of life than those participating in physiotherapy for a period shorter than 8 weeks (Table 5).

\section{Discussion}

In the presented study, an attempt was undertaken to assess the quality of life of patients who had undergone arthroscopic reconstruction of the rotator cuff, using the Polish version of the WORC questionnaire. This research instrument was also applied in the studies by Holtby et al., Kirkley et al., and de Witte et al., who emphasised the reliability, validity, and sensitivity of this questionnaire to changes [17-20].

Osti et al. evaluated the quality of life of patients after rotator cuff repair using for this purpose, among others, the SF-36 questionnaire assessing eight indicators of the quality of life. The examined patients demonstrated the highest quality of life in the domains: social functioning, mental health, and physical functioning, and the lowest in the domains: general health, role physical, and bodily pain [21].

The presented study showed that patients functioned best in the domains - physical symptoms and emotions, and worst in the domains work, and sports and recreation, which is consistent with the results obtained by Osti et al. In turn, Kang et al., in a retrospective study carried out in a group of 63 patients treated using the 'mini open' rotator cuff repair and 65 patients treated using arthroscopic reconstruction, reported a statistically significant improvement in all the parameters evaluated in the patients $(p \leq 0.001)$, except for the categories: general health, role physical, and mental health, assessed by means of the SF-36 questionnaire [22].

In addition, in the presented study the effect was also evaluated of the selected factors on the quality of life of patients after arthroscopic reconstruction of the rotary cuff. It was confirmed that from among all the factors analysed in this study a better quality of life was observed in patients with a higher level of education, occupationally active, performing intellectual work, and receiving rehabilitation for a period longer than 8 weeks. A similar study concerning the effect

Table 5. Relationships between quality of life according to the WORC and participation in physiotherapy

\begin{tabular}{|c|c|c|c|c|c|c|c|c|}
\hline \multirow[t]{2}{*}{ WORC } & \multicolumn{3}{|c|}{ Up to 8 weeks } & \multicolumn{3}{|c|}{ Longer than 8 weeks } & \multirow[t]{2}{*}{$Z$} & \multirow[t]{2}{*}{$P$-value } \\
\hline & $\bar{x}$ & $\mathrm{Me}$ & SD & $\bar{x}$ & Me & SD & & \\
\hline Physical symptoms & 71.63 & 71.33 & 21.34 & 86.63 & 93.25 & 15.38 & 3.02 & 0.002 \\
\hline Sports and recreation & 56.41 & 50.00 & 30.37 & 74.69 & 82.50 & 23.87 & 2.36 & 0.018 \\
\hline Work & 51.85 & 42.50 & 32.02 & 75.68 & 81.13 & 24.48 & 2.85 & 0.004 \\
\hline Lifestyle & 65.58 & 64.75 & 27.50 & 84.50 & 93.25 & 19.08 & 2.63 & 0.009 \\
\hline Emotions & 69.34 & 81.67 & 26.68 & 85.24 & 95.00 & 18.03 & 2.55 & 0.011 \\
\hline Total & 63.49 & 60.24 & 25.52 & 81.66 & 88.62 & 18.52 & 2.96 & 0.003 \\
\hline
\end{tabular}

WORC - Western Ontario Rotator Cuff Index, $\bar{x}$ - arithmetic mean, Me - median, SD - standard deviation, Z - result of Mann-Whitney $U$ test, $p$ - level of significance of differences. 
of the selected factors on patient satisfaction after reconstructive shoulder surgery was also conducted by Baettig et al. [23] in a group of 505 patients, considering 21 personal and socio-demographic parameters. Their study demonstrated that patients at an older age, who possessed private health insurance, had undergone the surgery for the first time, were non-smokers, and did not abuse alcohol showed higher satisfaction after the surgery. Occupational activity and the type of work (light physical work) were related with considerably higher patient satisfaction. According to the presented study, occupational activity and intellectual work were also associated with higher patient satisfaction.

Moreover, in compliance with the presented study, the researchers did not find any correlation between patient satisfaction and marital status $(p=0.442)$, affected side $(p=0.502)$, dominance of the surgical limb $(p=0.521)$, and gender $(p=0.238)$ [23].

Kim et al. also conducted investigations concerning the prognostic factors exerting an effect on the quality of life (patient satisfaction and shoulder function) in patients after reconstruction of the rotator cuff tendon. In their study, these researchers used a questionnaire assessing patient satisfaction with surgical treatment of the rotary cuff from the aspect of physical activity and shoulder function. Analysis of the results showed that factors such as younger age, claims for workers' compensation, and lower education level were significant predictors of worse results assessed by means of the ASES ( $p<0.05)$, and a lower education level was the only independent predictor of a lower result evaluated using the SST $(p<0.01)$ [24]. These reports are consistent with the results of the presented study, in which a clear relationship may be observed that a higher education level is related with a better overall quality of life $(p=0.011)$.

In turn, Abtahi et al. investigated the effect of selected factors on the regeneration process after rotator cuff repair. They analysed, among other things, patient's age, tear size, fatty infiltration, and the effect of rehabilitation. Their study indicated that older age of a patient is a significant factor determining worse outcomes of healing of the rotator cuff tendons [25]. In their studies, Boileau et al. [26], Tashjian et al. [27], and Cho et al. [28] also arrived at similar conclusions.

In orthopaedic literature, the patient's age as a determining factor is discussed in a very controversial way. Our study did not reveal any statistically significant correlations between the respondents' quality of life, also with respect to symptoms and age. Abtahi et al. [25] also concluded that the size of tendon tears is a significant factor exerting an effect on the healing process, which is consistent with the results presented by Galatz et al. [29] and Chung et al. [30], who demonstrated that the tear size is the factor resulting in more frequent failure in tendon healing.
Lee et al. and Kim et al. examined the effect of rehabilitation as a prognostic factor for healing after arthroscopic regeneration. These researchers concluded that an early aggressive rehabilitation may result in an increase in insufficiency of the tendons repaired, while a mild long-lasting rehabilitation with limited scope of motion and exercises during an early period after surgery is better for the process of tendon healing $[31,32]$. The presented study also showed that rehabilitation carried out for the period of longer than eight weeks was one of the factors exerting an effect on a higher quality of life of patients.

In their study, Chung et al. analysed the effect of prognostic factors related with structural outcome after arthroscopic rotator cuff repair. Based on multiple-factor analysis they concluded that bone mineral density $\operatorname{BMD}(p=0.001)$, fatty infiltration of the infraspinatus $(p=0.01)$, and tear size $(p=0.03)$ are independent factors determining post-operative treatment [33].

In other studies, also conducted by Chung et al., the researchers evaluated the quality of life and analysed clinical factors in patients with arthroscopic reconstruction of the rotator cuff using the SF-36 questionnaire. The study included 309 patients followed-up for a mean of 26.3 months (range: 12-48 months) after arthroscopic procedure, whose quality of life was periodically measured using the SF-36 - before the surgery, a year after surgery, and at the final examination (after a maximum of 48 months). The results obtained using SF-36 for physical and mental domains indicated a considerable improvement a year after the surgery, from 40.40 to 47.53 and from 44.45 to 50.55 , respectively, while in the final period of follow-up the improvement remained on the level of 48.24 and 50.45, respectively. According to the researchers, after 12 months and after the last examination following surgery, only the factors such as older age, female gender, presence of diabetes, and low level of sports activity exerted a negative effect on postoperative quality of life in the physical domain [34]. In the study conducted by Baysal and Balyk concerning functional outcomes and the quality of life of patients who had undergone rotator cuff repair using the 'mini-open' technique, an improvement was observed in mean results according to WORC, from 43.2 prior to surgical intervention to 87.2 after the procedure $(p<0.001)$. According to the above-mentioned researchers, this indicates an improvement in shoulder function and health-related quality of life within the period of 5 years after surgery [35].

In the subsequent comprehensive study carried out by Feng et al. concerning the prognostic indicators associated with the outcomes of retrospective assessment of 1120 patients after rotator cuff repair, positive correlations were observed between tear type, degree of degeneration, surgical technique and pre-operative 
pain. Interestingly, in contrast to the presented study, the researchers also indicated that ageing (age) should be considered as the most important factor contributing to the deterioration of the quality of life through its effect on the pathogenesis of rotator cuff tears [36]. In turn, Charousset et al., who evaluated 114 patients (53 males and 61 females) using arthroscopic reconstruction of the rotator cuff, observed that female gender is a negative prognostic factor for clinical outcomes at a minimum of two years after surgery. Similar findings were reported in the study by Cho et al., who suggested that female gender exerts an effect on early prognostic results $[37,38]$. Nevertheless, O`Holleran et al., who examined a group of 216 males and 95 females, reported that gender was not a factor that affects satisfaction and improvement of the quality of life after rotator cuff repair [39]. Similar results were also reported by Kim et al. [24] and Baettig et al. [23]. In addition, in the previously mentioned study by Feng et al. [36], who assessed 1120 shoulders (872 males and 248 females), the researchers also found that gender was not the factor correlated with post-operative outcome. Analysis of the results of the presented study showed that the quality of life of females after surgery was better than that of males; however, these differences were statistically insignificant $(p=0.355)$.

As can be seen from the examples of reports by other researchers, various clinical factors, such as: age, gender, tear size, physical activity, rehabilitation process, and others, to various degrees exert an effect on the quality of life of patients with rotator cuff tears. Frequently, studies by various researchers provide divergent results with respect to the quality of life and its relations with the determining factors. Therefore, it is advisable to conduct further studies and analyse the results with the consideration of a larger number of prognostic factors, as well as a larger group of patients.

\section{Conclusions}

The highest quality of life of patients after arthroscopic reconstruction of the rotator cuff was observed in the following domains: physical symptoms, emotions, and lifestyle, whereas the lowest quality of life was in the domains: work, and sports and recreation. The respondents' university education level, occupational activity, performance of intellectual work, and rehabilitation lasting for a period longer than 8 weeks are factors that strongly determine the quality of life of patients. No significant relationships were found between the quality of life of the examined patients and their age, gender, place of residence, marital status, and dominance of the surgical limb. Physical symptoms as a domain of the WORC most strongly determined the respondents' overall quality of life.

\section{Conflict of interest}

The authors declare no conflict of interest.

\section{References}

1. Lemiesz G, Iwańczyk K, Dąbrowski M. Najczęstsze dolegliwości bólowe kompleksu łopatkowo-ramiennego. Prakt Fizjoter Rehabil 2016; 4: 6-22.

2. Dobosz M. Wpływ uszkodzenia mięśnia nadgrzebieniowego na stabilność i mobilność obręczy barkowej. Praca magisterska, Katowice 2009.

3. Kassolik K, Andrzejewski W, Trzęsicka E, Ostrowska B. Ocena skuteczności masażu medycznego w zespole bolesnego barku. Fizjoter Pol 2005; 5: 201-6.

4. Kassolik K, Andrzejewski W. Masaż tensegracyjny. MedPharm Polska, Wrocław 2014.

5. Majdan M, Metera K. Diagnostyka funkcjonalna i leczenie uszkodzeń tkanek miękkich stawu barkowego w wybranych metodach fizjoterapii. Zeszyty naukowe WSSP 2013; 17: 149-74.

6. Białoszewski D, Zaborowski G. Przydatność terapii manualnej w rehabilitacji pacjentów z przewlekłym uszkodzeniem stożka rotatorów stawu ramiennego. Doniesienia wstępne. Ortop Traumatol Rehab 2011; 13: 9-20.

7. Struzik S, Glinkowski W, Górecki A. Powikłania po artroskopii barku. Ortop Traumatol Rehab 2003; 4: 489-94.

8. Altchek DW, Warren RF, Wićkiewicz TL, Wickiewicz TL, Skyhar MJ, Ortiz G, Schwartz E. Arthroscopic acromioplasty: techniques and results. J Bone Joint Surg 1990; 72: 1198-207.

9. Nuber GW, Bowen MK. Arthroscopic treatment of acromioclavicular joint injures and results. Clin Sports Med 2003; 22: 301-17.

10. Mazzocca AD, Arciero RA, Shea KP. The effect of early range of motion on quality of life, clinical outcome, and repair integrity after arthroscopic rotator cuff repair. Arthroscopy 2017; 33: 1138-48.

11. WHOQOL Group. The World Health Organisation quality of life assesment (WHOQOL): position paper from the world Health Organisation. Soc Sci Med 1995; 41: 1403-9.

12. Krawczyńska J, Łukawska P. Health-related quality of life of adolescents in the context of selected somatic development indices. Studia Medyczne 2016; 32: 189-95.

13. Brola W, Sobolewski P, Fudala M, Flaga S, Jantarski K. Multiple sclerosis: patient-reported quality of life in the Świętokrzyskie Region. Studia Medyczne 2017; 33: 191-8.

14. Papuć E. Jakość życia - definicje i sposoby jej ujmowania. Curr Probl Psychiatry 2011; 12: 141-5.

15. Kirkley A, Alvarez C, Griffin S. The development and evaluation of a disease-specific quality-of-life questionnaire for disorders of the rotator cuff: The Western Ontario Rotator Cuff Index. Clin J Sport Med 2003; 13: 84-92.

16. Bejer A, Probachta M, Kulczyk M, Griffin S. The Western Ortario rotator cuff index (WORC) - the Polish language version. Issue Rehabil Orthop Neurophysiol Sport Promot 2017; 20: 20-9.

17. Holtby R, Razmjou H. Measurement properties of the Western Ontario rotator cuff outcome measure: a preliminary report. J Shoulder Elbow Surg 2005; 14: 506-10.

18. Kirkley A, Griffin S, Dainty K. Scoring systems for the functional assessment of the shoulder. Arthroscopy 2003; 19: $1109-20$ 
19. Kirkley A, Alvarez C, Griffin S. The development and evaluation of a disease-specific quality-of-life questionnaire for disorders of the rotator cuff: the Western Ontario Rotator Cuff Index. Clin J Sport Med 2003; 13: 84-92.

20. de Witte PB, Henseler JF, Nagels J, Vliet Vlieland TP, Nelissen RG. The Western Ontario rotator cuff index in rotator cuff disease patients: a comprehensive reliability and responsiveness validation study. Am j Sports Med 2012; 40 1611-9.

21. Osti L, Papalia R, Paganelli M, Denaro E, Maffulli N. Arthroscopic vs mini-open rotator cuff repair. A quality of life impairment study. Int Orthop 2010; 34: 389-94.

22. Kang L, Henn RF, Tashjian RZ, Green A. Early outcome of arthroscopic rotator cuff repair: a matched comparison with mini-open rotator cuff repair. Arthroscopy 2007; 23: 573-82.

23. Baettig SJ, Wieser K, Gerber C. Determinants of patient satisfaction following reconstructive shoulder surgery. BCM Musculoscelet Disord 2017; 18: 458.

24. Kim HM, Caldwell JM, Buza JA, Fink LA, Ahmad CS, Bigliani LU, Levine WN. Factors affecting satisfaction and shoulder function in patients with a recurrent rotator cuff tear. J Bone Joint Surg Am 2014; 96: 106-12.

25. Abtahi AM, Granger EK, Tashjian RZ. Factors affecting healing after arthroscopic rotator cuff repair. World J Orthop 2015; 6: 211-20.

26. Boileau P, Brassart N, Watkinson DJ, Carles M, Hatzidakis AM, Krishnan SG. Arthroscopic repair of full-thickness tears of the supraspinatus: does the tendon really heal? J Bone Joint Surg Am 2005; 87: 1229-40.

27. Tashjian RZ, Hollins AM, Kim HM, Teefey SA, Middleton WD, Steger-May K, Galatz LM, Yamaguchi K. Factors affecting healing rates after arthroscopic double-row rotator cuff repair. Am J Sports Med 2010; 38: 2435-42.

28. Cho NS, Lee BG, Rhee YG. Arthroscopic rotator cuff repair using a suture bridge technique: is the repair integrity actually maintained? Am J Sports Med 2011; 39: 2108-16.

29. Galatz LM, Ball CM, Teefey SA, Middleton WD, Yamaguchi $\mathrm{K}$. The outcome and repair integrity of completely arthroscopically repaired large and massive rotator cuff tears. J Bone Joint Surg Am 2004; 86: 219-24.

30. Chung SW, Kim JY, Kim MH, Kim SH, Oh JH. Arthroscopic repair of massive rotator cuff tears: outcome and analysis of factors associated with healing failure or poor postoperative function. Am J Sports Med 2013; 41: 1674-83.

31. Lee BG, Cho NS, Rhee YG. Effect of two rehabilitation protocols on range of motion and healing rates after arthroscopic rotator cuff repair: aggressive versus limited early passive exercises. Arthroscopy 2012; 28: 34-42.

32. Kim YS, Chung SW, Kim JY, Ok JH, Park I, Oh JH. Is early passive motion exercise necessary after arthroscopic rotator cuff repair? Am J Sports Med 2012; 40: 815-21.

33. Chung SW, Oh JH, Gong HS, Kim JY, Kim SH. Factors affecting rotator cuff healing after arthroscopic repair: osteoporosis as one of the independent risk factors. Am J Sports Med 2011; 39: 2099-107.

34. Chung SW, Park JS, Kim SH, Shin SH, Oh JH. Quality of life after arthroscopic rotator cuff repair: evaluation using SF-36 and an analysis of affecting clinical factors. Am J Sports Med 2012; 40: 631-9.

35. Baysal D, Balyk R, Otto D, Luciak-Corea C, Beaupre L. Functional outcome and health-related quality of life after surgical repair of full-thickness rotator cuff tear using a mini-open technique. Am J Sports Med 2005; 33 : 1346-55.

36. Feng S, Guo S, Nobuhara K, Hashimoto J, Mimori K. Prognostic indicators for outcome following rotator cuff tear repair. J Orthop Surg 2003; 11: 110-6.

37. Charousset C, Grimberg J, Duranthon LD, Bellaïche L, Petrover D, Kalra K. The time for functional recovery after arthroscopic rotator cuff repair: correlation with tendon healing controlled by computed tomography arthrography. Arthroscopy 2008; 24: 25-33.

38. Cho CH, Ye HU, Jung JW, Lee YK. Gender affects early postoperative outcomes of rotator cuff repair. Clin Orthop Surg 2015; 7: 234-40.

39. O’Holleran JD, Kocher MS, Horan MP, Briggs KK, Hawkins RJ. Determinants of patient satisfaction with outcome after rotator cuff surgery. J Bone Joint Surg Am 2005; 87: 121-6.

\section{Address for correspondence:}

\section{Jędrzej Płocki}

Department of Rehabilitation

Holy Family

Specialist Hospital

Rudna Mała 600

36-060 Głogów Młp, Poland

Phone: +48781529464

E-mail: jplocki@gazeta.pl 